medRxiv preprint doi: https://doi.org/10.1101/2020.07.25.20161943; this version posted July 27,2020 . The copyright holder for this preprint (which was not certified by peer review) is the author/funder, who has granted medRxiv a license to display the preprint in perpetuity. It is made available under a CC-BY 4.0 International license .

$16 / 07 / 2020$

- PREPRINT: This manuscript has not been peer-reviewed -

\title{
Evaluating SARS-CoV-2 spike and nucleocapsid proteins as targets for IgG antibody detection in severe and mild COVID-19 cases using a Luminex bead-based assay
}

Joachim Mariën ${ }^{1,3^{*}}$, Johan Michiels², Leo Heyndrickx², Karen Kerkhof², Nikki Foque ${ }^{3}$, MarcAlain Widdowson ${ }^{1}$, Isabelle Desombere ${ }^{4}$, Hilde Jansens ${ }^{5}$, Marjan Van Esbroeck ${ }^{3}$, Kevin K. Ariën ${ }^{2,6^{*}}$

\section{Affiliations}

${ }^{1}$ Outbreak Research Team, Institute of Tropical Medicine, Antwerp, Belgium

${ }^{2}$ Virology Unit, Deparment of Biomedical Sciences, Institute of Tropical Medicine, Antwerp, Belgium

${ }^{3}$ Department of Clinical Sciences Department, Institute of Tropical Medicine, Antwerp, Belgium

${ }^{4}$ Immune response, Sciensano, Brussels, Belgium

${ }^{5}$ University Hospital Antwerp, Antwerp, Belgium

${ }^{6}$ University of Antwerp, Antwerp, Belgium

*Corresponding authors: joachim_marien@hotmail.com; KArien@itg.be

\section{$\underline{\text { Abstract }}$}

Large-scale serosurveillance of severe acute respiratory syndrome coronavirus type 2 (SARSCoV-2) will only be possible if serological tests are sufficiently reliable, rapid and inexpensive. Current assays are either labour-intensive and require specialised facilities (e.g. virus neutralization assays), or expensive with suboptimal specificity (e.g. commercial ELISAs). Bead-based assays offer a cost-effective alternative and allow for multiplexing to test for antibodies of other pathogens. Here, we compare the performance of four antigens for the detection of SARS-CoV-2 specific IgG antibodies in a panel of sera that includes both severe $(n=40)$ and mild $(n=52)$ cases, using a neutralization and a Luminex bead-based assay. While we show that neutralising antibody levels are significantly lower in mild than in severe cases, we demonstrate that a combination of recombinant nucleocapsid protein (NP), receptorbinding domain (RBD) and the whole spike protein (S1S2) results in a highly sensitive (96\%) and specific (99\%) bead-based assay that can detect IgG antibodies in both groups. Although S1-specific IgG levels correlate most strongly with neutralizing antibody levels, they fall below the detection threshold in $10 \%$ of the cases in our Luminex assay. In conclusion, our data supports the use of RBD, NP and S1S2 for the development of SARS-CoV-2 serological beadbased assays. Finally, we argue that low antibody levels in mild/asymptomatic cases might complicate the epidemiological assessment of large-scale surveillance studies. 
medRxiv preprint doi: https://doi.org/10.1101/2020.07.25.20161943; this version posted July 27,2020 . The copyright holder for this preprint (which was not certified by peer review) is the author/funder, who has granted medRxiv a license to display the preprint in perpetuity. It is made available under a CC-BY 4.0 International license .

$16 / 07 / 2020$

\section{Introduction}

Since December 2019, Severe acute respiratory syndrome coronavirus type 2 (SARS-CoV-2) has spread at an unprecedented speed and scale, resulting in 500,000 deaths, 11,500,000 diagnosed cases (as of $10 / 7 / 2020)^{1}$ and likely many more undiagnosed cases with mild or no symptoms (10 fold $)^{2}$. Nucleic acid (PCR) tests are widely used for clinical diagnosis and provide good estimates on the duration of viral shedding ${ }^{3-5}$. However, it remains uncertain how many people develop protective antibodies after recovery and for how long ${ }^{6-8}$. Serological data is typically used to determine the overall attack rate and level of herd immunity in a given population, and lays the foundation for control and prevention policies.

Serological tests exist in a variety of different formats but not all are appropriate for largescale serosurveillance ${ }^{6-9}$. The gold standard for serological testing remains the virus neutralization test $(\mathrm{VNT})^{7}$. This assay format is very specific and directly assesses the neutralizing capacity of antibodies in serum ${ }^{10}$. However, VNTs are also labour-intensive and generally require highly trained staff to work in BSL3 laboratory conditions. In contrast, enzyme-linked immunosorbent assays (ELISAs) require less trained operators and allow highthroughput screening, but are usually less specific due to cross-reactivity with other coronaviruses or other pathogens. Furthermore, ELISAs are relatively expensive since sufficient recombinant antigens needs to be produced ${ }^{11}$. Nevertheless, many commercial ELISAs became rapidly CE-labelled and are currently used for serosurveillance studies ${ }^{7}$. Since ELISAs as well as VNTs have important limitations for large-scale serosurveillance, microsphere bead-based assays using the Xmap Luminex technology have been increasingly developped ${ }^{12-14}$. This high-throughput platform allows the simultaneous detection of antibodies against different antigens from SARS-CoV-2, which can significantly increase the specificity of serological testing, in contrast to ELISA that usually includes only one antigen. Additional advantages of the bead-based assays are the need for lower serum amounts $(<1 \mu l)$ and the lower cost (as less recombinant antigen is required) ${ }^{15}$.

Evaluating a set of compatible immunogenic antigens is essential for the development of these multiplex bead-based assays. For many SARS-CoV-2 antibody tests, the main targets are the large spike glycoprotein (S) and the nucleocapsid protein (NP) ${ }^{16}$. The $S$ protein is a trimeric class I fusion protein that consists of two subunits, namely S1 and S2 ${ }^{17,18}$. The S1 protein mediates binding to host cells via interactions with the human receptor angiotensin converting enzyme 2 (ACE2) and is very immunogenic with its receptor-binding domain (RBD) as the main target for neutralizing antibodies ${ }^{19}$. The $\mathrm{S} 2$ subunit regulates fusion of the viral and host cellular membrane. The $S$ protein, therefore, is an important target for the development of medical treatments and vaccines due to its role in cell binding and entry ${ }^{20}$. The NP plays a vital role in the transcription and replication of the virus, and is suggested to be more sensitive than the $S$ protein for detecting early infections ${ }^{16,21}$. Here, we evaluate the performance of these four antigens (NP, RBD, S1, S1S2; and combinations between them) for the detection of SARS-CoV-2 IgG antibodies in a bead-based assay using sera from severe and mild cases in the early convalescent phase (<6weeks). We also examine the correlations 
medRxiv preprint doi: https://doi.org/10.1101/2020.07.25.20161943; this version posted July 27,2020 . The copyright holder for this preprint (which was not certified by peer review) is the author/funder, who has granted medRxiv a license to display the preprint in perpetuity. It is made available under a CC-BY 4.0 International license .

$16 / 07 / 2020$

between levels of SARS-CoV-2 neutralizing antibodies and those of antigen-binding antibodies measured by our Luminex assay and the commercial IgG/IgA Euroimmun ELISA.

\section{Methods}

\section{Human serum samples}

We used a panel of 286 serum samples: 40 samples from 22 hospitalized COVID-19 patients (severe cases) at the University Hospital of Antwerp (UZA) and confirmed by RT-qPCR, 52 samples from COVID-19 positive healthcare workers confirmed to have antibodies by VNT (mild/asymptomatic cases), and 191 leftover samples from the travel clinic of the Institute of Tropical Medicine (ITM) in Antwerp that we expect to be antibody negative because they were sampled in November 2019 (negative cases). Samples from severe cases were collected between March, $3^{\text {th }}$ and April, $6^{\text {th }}$ from RT-qPCR confirmed COVID-19 cases (median days post symptom onset $=17$, Supplementary fig 1 ). Of these, 17 severe cases were sampled two or three times over a period of one or two weeks. Samples from healthcare workers were collected between April,22 ${ }^{\text {th }}$ and April,26 $6^{\text {th }}$ in 17 different hospitals in Belgium. From this group, 45 had mild symptoms (median days post symptom onset $=25$, Supplementary fig 1 ), four were asymptomatic and six had an unknown symptom status. At the time of serum sampling, health care workers were also checked for viral RNA using a nasopharyngeal swap (two were RT-qPCR positive) ${ }^{4}$. All serum samples from severe and mild/asymptomatic cases underwent a viral inactivation protocol by heating at $56^{\circ} \mathrm{C}$ for 30 minutes.

\section{SARS-CoV-2 neutralization test}

Serial dilutions of heat-inactivated serum (1/50-1/1600 dilutions in assay medium consisting of EMEM supplemented with $2 \mathrm{mM} \mathrm{L-glutamine,} 100 \mathrm{U} / \mathrm{ml}-100 \mu \mathrm{g} / \mathrm{ml}$ of PenicillinStreptomycin and $2 \%$ foetal bovine serum) were incubated with $3 \times \mathrm{TCI}_{100}$ of a primary isolate of SARS-CoV-2 during $1 \mathrm{~h}\left(37^{\circ} \mathrm{C} / 7 \% \mathrm{CO}_{2}\right)$. Sample-virus mixtures and virus/cell controls were added to Vero cells (18.000cells/well) in a 96well plate and incubated for 5 days $\left(37^{\circ} \mathrm{C} / 7 \%\right.$ $\mathrm{CO}_{2}$ ). The cytopathic effect caused by viral growth was scored microscopically. The ReedMuench method was used to calculate the neutralising antibody titre that reduced the number of infected wells by $50 \%$ (NT50) or $90 \%$ (NT90) $^{22}$, these values were used as proxy for the neutralizing antibody concentration in each sample.

\section{Luminex bead-based IgG immunoassay}

We ordered commercially available recombinant NP, RBD, S1 and the complete Spike unit (S1S2) antigens derived from SARS-CoV-2 at Sino Biological (BIOCONNECT, Huissen, The Netherlands). The lyophilized proteins were resuspended in a buffer according to the manufacturer's instructions and stored until use. Each antigens was coupled to a maximum of $10^{6}$ paramagnetic MAGPLEX $\mathrm{COOH}$-microspheres beads from Luminex Corporation (Austin, TX), as described previously ${ }^{15,23}$. Each antigen was coupled at a concentration of $3 \mu \mathrm{g}$ per

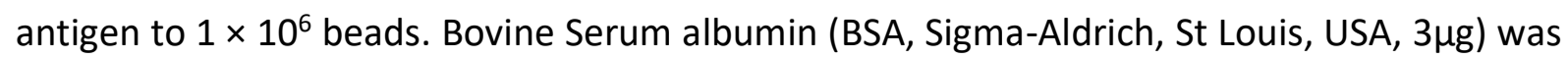
coupled to an additional set of beads to serve as background control. 
medRxiv preprint doi: https://doi.org/10.1101/2020.07.25.20161943; this version posted July 27, 2020. The copyright holder for this preprint (which was not certified by peer review) is the author/funder, who has granted medRxiv a license to display the preprint in perpetuity. It is made available under a CC-BY 4.0 International license .

$16 / 07 / 2020$

A microsphere working mixture was prepared in a phosphate buffered saline-BSA (PBS-BN) solution with a concentration of 2,000 beads/antigen/well. To choose an appropriate serum concentration, IgG titers were measured in serial dilutions $(1 / 200-1 / 3,000)$ for five positive and three negative samples. We observed that a $1 / 1000$ serum dilution gave the best signal to noise ratio (Supplementary Fig 2). Beads and diluted sera (1/1000) were added to each well in a final volume of $100 \mu \mathrm{l}$. Plates were incubated at room temperature for two hours in the dark, and then washed three times with $200 \mu \mathrm{l} /$ well of $0.05 \%$ PBS-Tween 20 . Subsequently, $100 \mu$ of a 1:400 secondary antibody (R-phycoerythrin-conjugated AffiniPure F(ab')2 fragment of goat anti-human IgG, Jackson Immuno Research Laboratories) dilution in PBS-BN was added to each well. Plates were incubated for $45 \mathrm{~min}$ in the dark at room temperature on a plate shaker (600rpm) and washed twice with PBS-BN-Tween. Beads were resuspended in $100 \mu \mathrm{l}$ PBS-BN and read using a Luminex ${ }^{\circledR} 100 / 200$ analyzer with $50 \mu$ acquisition volume per well, DD gat 5000-25000 settings, and high PMT option. Results were expressed as crude median fluorescent intensities (MFI). The standard operating procedure for the bead-coupling and the assay is included in the supplementary material (SOP_Luminex).

\section{EUROIMMUN IgG/IgA ELISA}

Samples from hospitalized cases were also analysed for level of antigen-binding antibodies against SARS-CoV-2 using the Anti-SARS-CoV-2 ELISA (IgA) and Anti-SARS-CoV-2 ELISA (IgG) (Euroimmun, Lübeck, Germany) following the manufacturer's instructions. A ratio (optical density of the sample divided by optical density of the cut-off calibrator) $<0.8$ is considered negative, $\geq 0.8$ and $<1.1$ borderline, and $\geq 1.1$ positive ${ }^{7}$. The IgG and IgA Euroimmun ELISAs use the S1 spike protein, allowing comparison with S1-antibody levels of our Luminex assay.

\section{Statistical evaluation and diagnostic performance}

To correct for background noise, we first subtracted the BSA-coupled bead signal ( $\mathrm{MFI}_{\mathrm{BSA}}$ ) from the median antigen-coupled bead signal ( $\mathrm{MFl}_{\mathrm{ag}}$ ), resulting in $\triangle \mathrm{MFI}$ for each serum sample. We then investigated if mean $\triangle M F I$ levels (NP, RBD, S1, S1S2) differ significantly between serum of COVID-19 positive and negative cases using a student's t-test. Subsequently, we tested if $\triangle \mathrm{MFI}$ and neutralizing antibody levels differed significantly between serum of severe and mild cases using linear models. Because samples from the healthcare worker group were taken on average eight days later after symptom onset than samples from hospitalized patients $(t=4.3781, d f=77.962, p=<0.0001$, Supplementary Fig 1$)$, we corrected for a potential sampling time effect by including days post symptom onset (dpo) in interaction with symptom status (severe vs mild). Neutralizing antibody levels were log-transformed to meet normality assumptions. When fitting the linear models, we started with the fully parameterised model (interaction between both independent fixed variables) and sequentially dropped variables that had the highest insignificant $p$-values. Significance was tested with the likelihood ratio test (assuming a $\chi^{2}$ residual distribution). Furthermore, to test if antibody levels increase and stabilize for the severe group, we plotted individual $\Delta M F I$ values and neutralizing antibody levels for patients that were repeatedly sampled in function of dpo. 
medRxiv preprint doi: https://doi.org/10.1101/2020.07.25.20161943; this version posted July 27,2020 . The copyright holder for this preprint (which was not certified by peer review) is the author/funder, who has granted medRxiv a license to display the preprint in perpetuity.

It is made available under a CC-BY 4.0 International license .

$16 / 07 / 2020$

We assessed the sensitivity and specificity of the Luminex bead-based assay by looking at Receiver Operating Characteristics (ROC) curves. First, sensitivity and specificity were tradedoff to calculate cut-off values for SARS-CoV2 antigens in singleplex. To test which combinations of antigens could improve the accuracy of the test in multiplex, we checked ROC curves calculated by supervised machine learning Random Forest (RF) algorithm models, as implemented in the R-package 'randomForest'24. Variable (antigen) importance was assessed using the 'varlmplot' function of the same package. Antigens with the lowest 'mean decrease in accuracy' and 'mean decrease in Gini' were sequentially removed from the bead set. Selection of optimal antigen combinations was performed based on the Area Under a Curve (AUC) values.

To assess the relationship between the different antigens and the neutralizing antibody response, we correlated the NT50 and NT90 measurements to $\triangle \mathrm{MFI}$ and ELISA calibrator ratios using a Spearman's rank ( $r s$ ) test. To compare if beads coated with S1 antigen can be used as an alternative for the EUROIMMUN ELISA S1, we also correlated ELISA calibrator ratios to $\Delta \mathrm{MFI}_{\mathrm{S} 1}$ values. All analyses were performed in the statistical software R.3.6.1.

\section{Results}

\section{Differences in antibody levels between severe and mild cases}

We first investigated whether $\triangle M F I$ levels for antigens (NP, RBD, S1, S1S2) differ between severe cases and mild cases, and the negative controls. The $\triangle M F I$ was significantly higher $(p<0.0001)$ for positive than negative cases for all antigens (Supplementary Fig 1 ), indicating that antigen-coated beads can be used to discriminate positive from negative sera in singleplex. Neutralizing antibody (NT50 and NT90) and $\triangle \mathrm{MFI}$ levels were also significantly higher for severe than for mild cases, although the significance level for $\Delta \mathrm{MFI}_{\mathrm{NP}}$ lay just below the 0.05 cut-off value (Table 1; Fig 1). A significant increase of antibody level in function of dpo was only observed for the NT50 and NT90 in the severe group (p-value=0.02), which were on average sampled eight days earlier than the mild ones (Fig 2). Consequently, neutralizing antibody and $\triangle \mathrm{MFI}$ levels increased or remained constant for the majority of severe cases ( $n=16 / 18$ ) that were repeatedly sampled 5-36dpo (Supplementary Fig 3 and 4).

Table1: P-values expressing the effects of disease severity (severe vs mild) on antibody levels as measured by the Luminex or VNT corrected for days post symptom onset (DPO)

\begin{tabular}{llrrr}
\hline Test & Antigen/NT & \multicolumn{1}{c}{ DPO } & Severity & \multicolumn{1}{c}{ DPO x Severity } \\
\hline \multirow{4}{*}{ Luminex } & NP & 0.34 & 0.04 & 0.35 \\
& RBD & 0.76 & 0.01 & 0.52 \\
& S1 & 0.28 & $<0.0001$ & 0.71 \\
\multirow{4}{*}{ Neutralization } & S1S2 & 0.83 & $<0.0001$ & 0.78 \\
& Log(NT50) & Interaction & $<0.0001$ & 0.02 \\
& Log(NT90) & Interaction & $<0.0001$ & 0.02 \\
\hline
\end{tabular}


medRxiv preprint doi: https://doi.org/10.1101/2020.07.25.20161943; this version posted July 27, 2020. The copyright holder for this preprint (which was not certified by peer review) is the author/funder, who has granted medRxiv a license to display the preprint in perpetuity.

It is made available under a CC-BY 4.0 International license.

$16 / 07 / 2020$

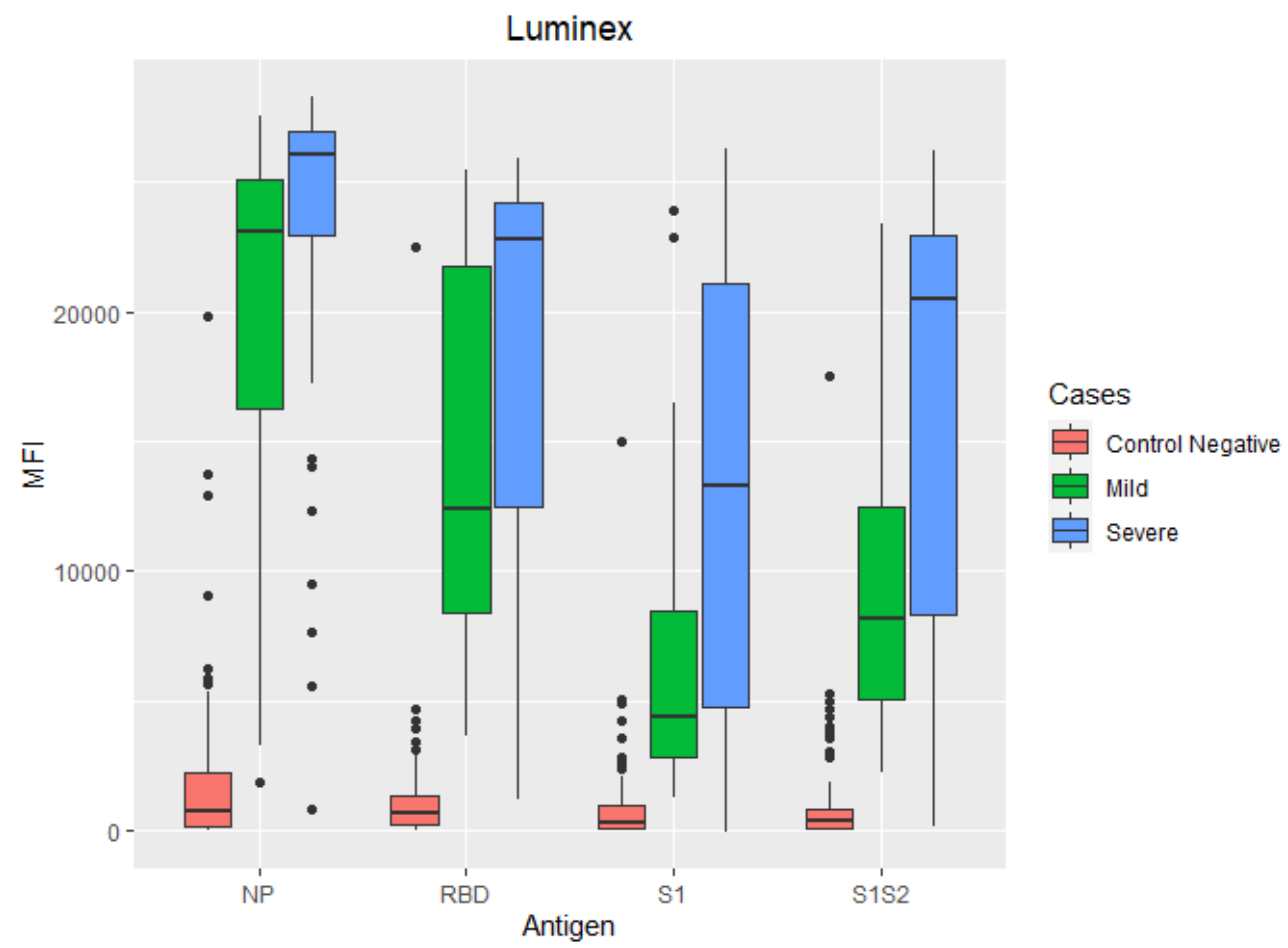

Fig 1: Boxplots representing differences in $\triangle M F I$ levels for NP, RBD, S1 and S1S2 between the severe ( $n=40$, blue), mild cases ( $n=52$, green) and the negative control ( $n=191$, red) group.

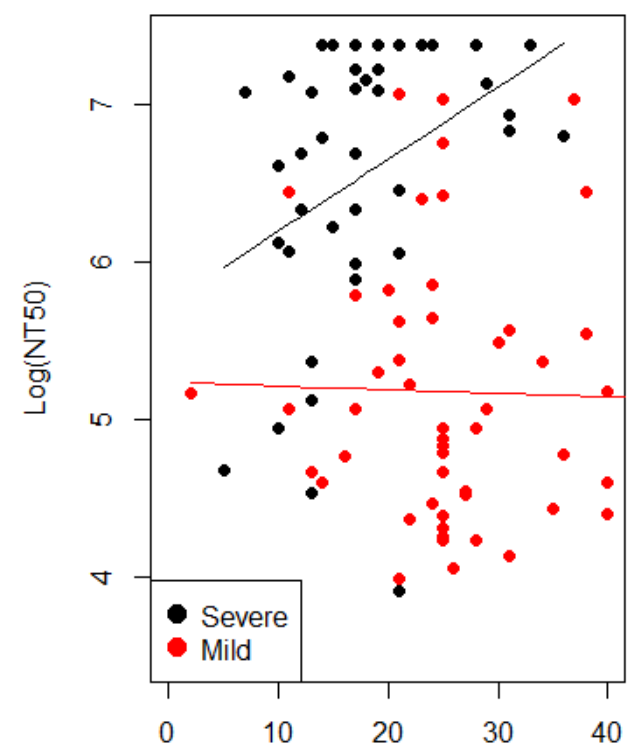

Days post symptom onset

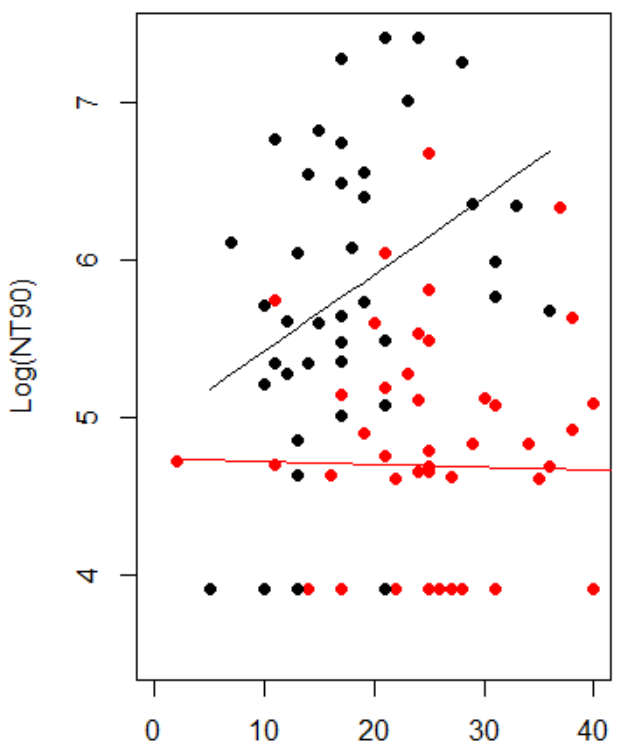

Days post symptom onset

Fig2: Comparison between log-transformed neutralizing antibody titers (NT50 and NT90) for severe (black) and mild cases (red) corrected for days post symptoms onset. Lines indicate the mean antibody level increase in function of dpo as predicted by the linear models. 
medRxiv preprint doi: https://doi.org/10.1101/2020.07.25.20161943; this version posted July 27, 2020. The copyright holder for this preprint (which was not certified by peer review) is the author/funder, who has granted medRxiv a license to display the preprint in perpetuity.

It is made available under a CC-BY 4.0 International license .

$16 / 07 / 2020$

\section{Performance assessment of the Luminex bead-based assay}

Sensitivity, specificity and cut-off values were first calculated for individual antigens using a ROC analysis (Fig 3 and Table 2). The large variation in AUC values suggests significant differences in classification performance for each antigen in singleplex. RBD had the highest classification performance ( $A \cup C=0.97$ ) and $S 1$ the lowest ( $A \cup C=0.83$ ), while S1S2 ( $A \cup C=0.95$ ) and NP (AUC=0.94) had almost the same classification performance. Subsequently, we calculated cut-off levels for each antigen by balancing sensitivity and specificity so that both were approximately equal. Similarly, the highest specificity and sensitivity were obtained for RBD and the lowest for S1. Final $\triangle$ MFI cut-off levels were: 3531 (RBD), 3621 (S1S2), 5507 (NP) and 1835 (S1) (Fig 4).

Subsequently, we used a random forest algorithm to test if combinations of different antigens could improve the classification performance of the assay. While multiplexing all antigens gave the best specificity (99\%), the removal of S1 did not change the AUC (0.993) and sensitivity (96\%) while the specificity decreased by $0.3 \%$ only. The variable importance scores ('mean decrease in accuracy' and 'mean decrease in Gini') also suggested that S1 can be removed from the multiplex without serious reduction in classification performance (Supplementary Fig 5). If we removed S1S2 (second lowest variable importance score), the prediction performance of the model decreased by $\triangle A U C=0.001$.
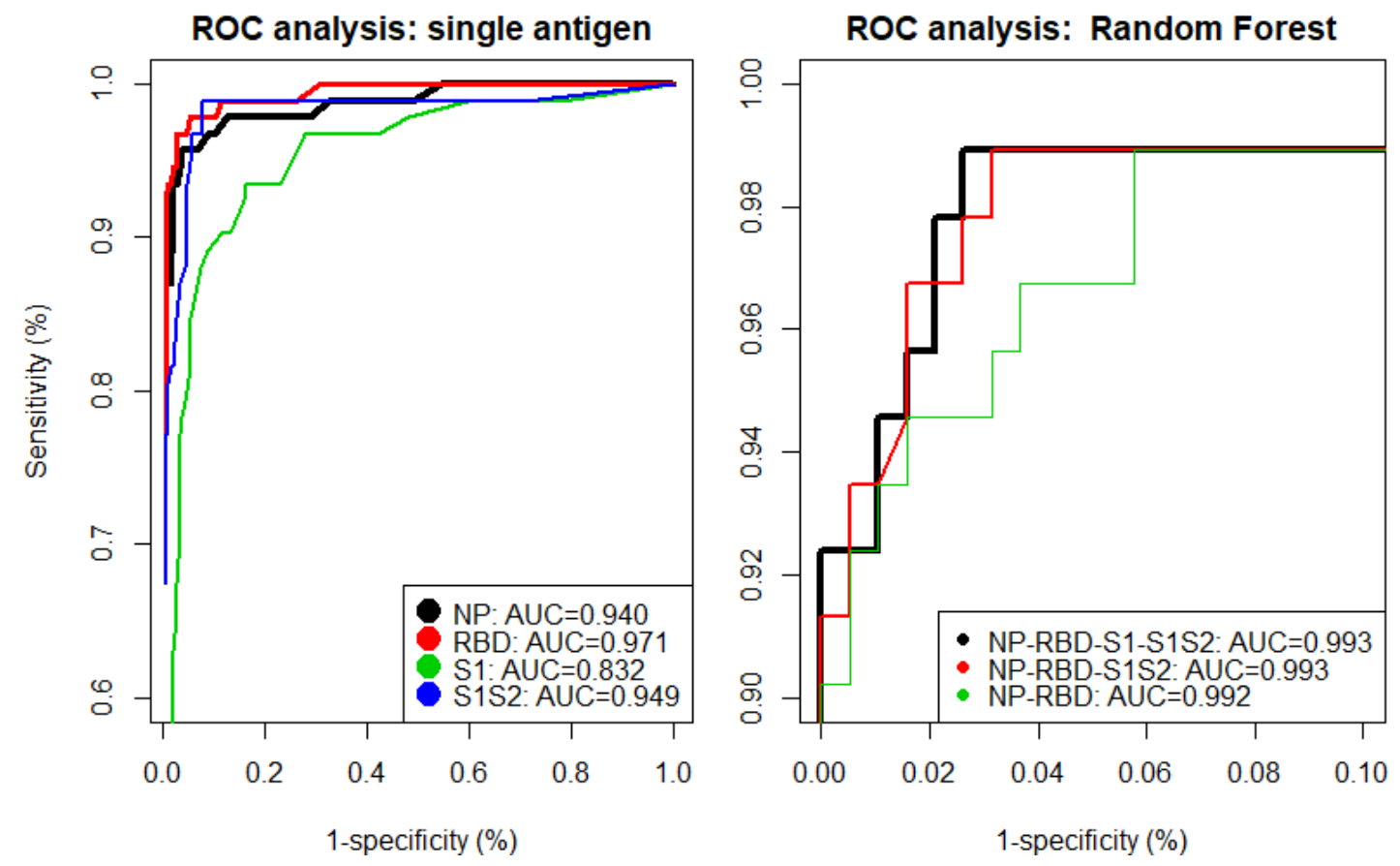

Fig 3: Receiver Operating Characteristic (ROC) curves obtained by varying the $\Delta M F I$ cut-off levels for antigens in singleplex (left figure); or combinations of antigens in multiplex as calculated by a random forest algorithm (right figure). The area under the curve (AUC) was used to evaluate the antigen's classification performance. 
medRxiv preprint doi: https://doi.org/10.1101/2020.07.25.20161943; this version posted July 27,2020 . The copyright holder for this preprint (which was not certified by peer review) is the author/funder, who has granted medRxiv a license to display the preprint in perpetuity.

It is made available under a CC-BY 4.0 International license .

$16 / 07 / 2020$

Table 2: Sensitivity and specificity of the Luminex antibody assay for antigens in single- and multiplex.

\begin{tabular}{llrrr}
\hline Antigen(s) & AUC & \multicolumn{1}{c}{ sensitivity (\%) } & specificity (\%) & $\begin{array}{l}\text { cut-off }(\Delta \mathbf{M F I}) / \\
\text { random forest }\end{array}$ \\
\hline NP-RBD-S1-S1S2 & 0.993 & 96 & 99 & Random forest \\
NP-RBD-S1S2 & 0.993 & 96 & 99 & Random forest \\
NP-RBD & 0.992 & 96 & 97 & Random forest \\
RBD & 0.971 & 96 & 97 & 3531 \\
S1S2 & 0.949 & 94 & 97 & 3621 \\
NP & 0.940 & 96 & 96 & 5507 \\
S1 & 0.832 & 89 & 91 & 1835 \\
\hline
\end{tabular}

\section{Correlations between neutralizing antibody, $\triangle M F I$ and ELISA levels}

To assess if $\triangle \mathrm{MFI}$ and ELISA levels can be used as proxy for the neutralizing capacity of serum, we correlated these levels to the NT50 (Fig 4) and NT90 (Supplementary Fig 6). We found overall moderate to strong correlations between $\triangle \mathrm{MFI}$ values from antigens belonging to the S-protein and the NT50 ( $r s=0.58-0.67, p<0.0001$ ) and NT90 ( $r s=0.59-0.68, p<0.0001$ ), but a rather weak correlation between $\Delta \mathrm{MFI}_{\mathrm{NP}}$ and $\mathrm{NT50}$ ( $\left.\mathrm{rs}=0.43, \mathrm{p}=0.0001\right)$ and $\mathrm{NT90}$ ( $r s=0.41$, $\mathrm{p}=0.0001$ ). This pattern can be explained by the observation that $\Delta \mathrm{MFI}_{\mathrm{NP}}$ already reached its maximum $\left(\Delta \mathrm{MFI}_{\max }=28.000\right)$ at low neutralizing levels, which was not the case for $\Delta \mathrm{MFI}_{\mathrm{s} 1}$ and $\Delta \mathrm{MFI}_{\mathrm{S} 1 \mathrm{~s} 2}$. We also found that neutralizing antibody levels correlated stronger to $\Delta \mathrm{MFI}$ levels of mild than severe cases (Supplementary table 1). Interestingly, NT50 ( $\rho=0.71, p<0.0001)$ and NT90 ( $r s=0.73, p<0.0001$ ) correlated most strongly with IgA ELISA ratios (Fig 5). As expected, levels of $\Delta \mathrm{MFI}_{\mathrm{S1}}$ and IgG ELISA ratios also correlated strongly ( $r s=0.73, p<0.0001, \mathbf{S}$ Fig 7).

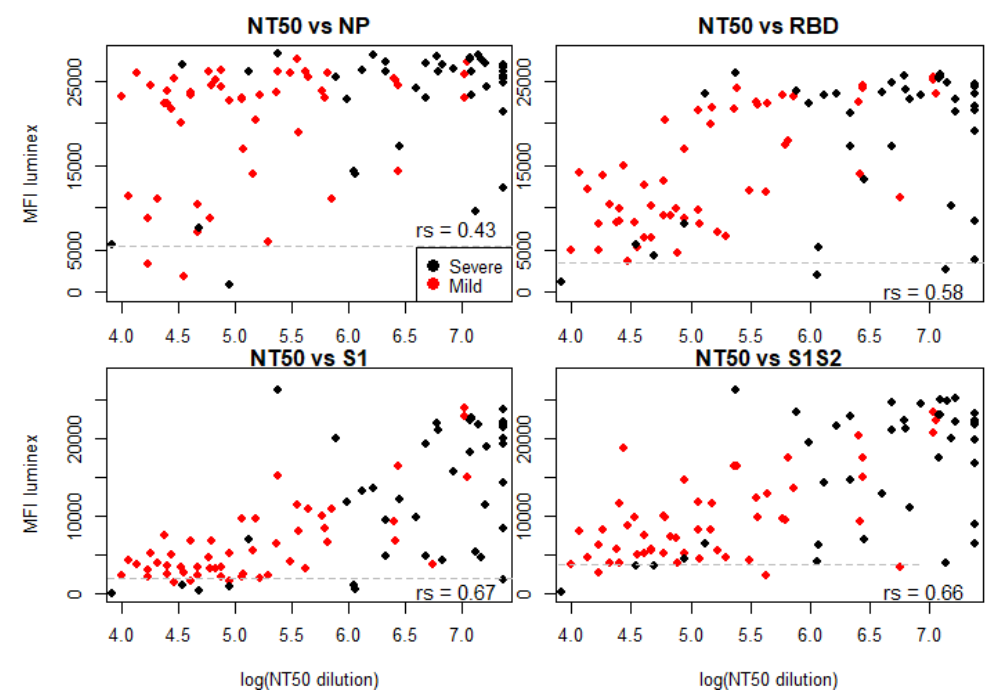

Fig 4: Correlations between NT50 and $\triangle M$ MFI levels to NP, RBD, S1 and S1S2. Red dots represent serum from mild and black dots serum from severe COVID-19 cases, as calculated by the nonparametric Spearman correlation test (rs). Seropositivity cut-off levels are indicated by the dashed grey lines. 
medRxiv preprint doi: https://doi.org/10.1101/2020.07.25.20161943; this version posted July 27,2020 . The copyright holder for this preprint (which was not certified by peer review) is the author/funder, who has granted medRxiv a license to display the preprint in perpetuity. It is made available under a CC-BY 4.0 International license .
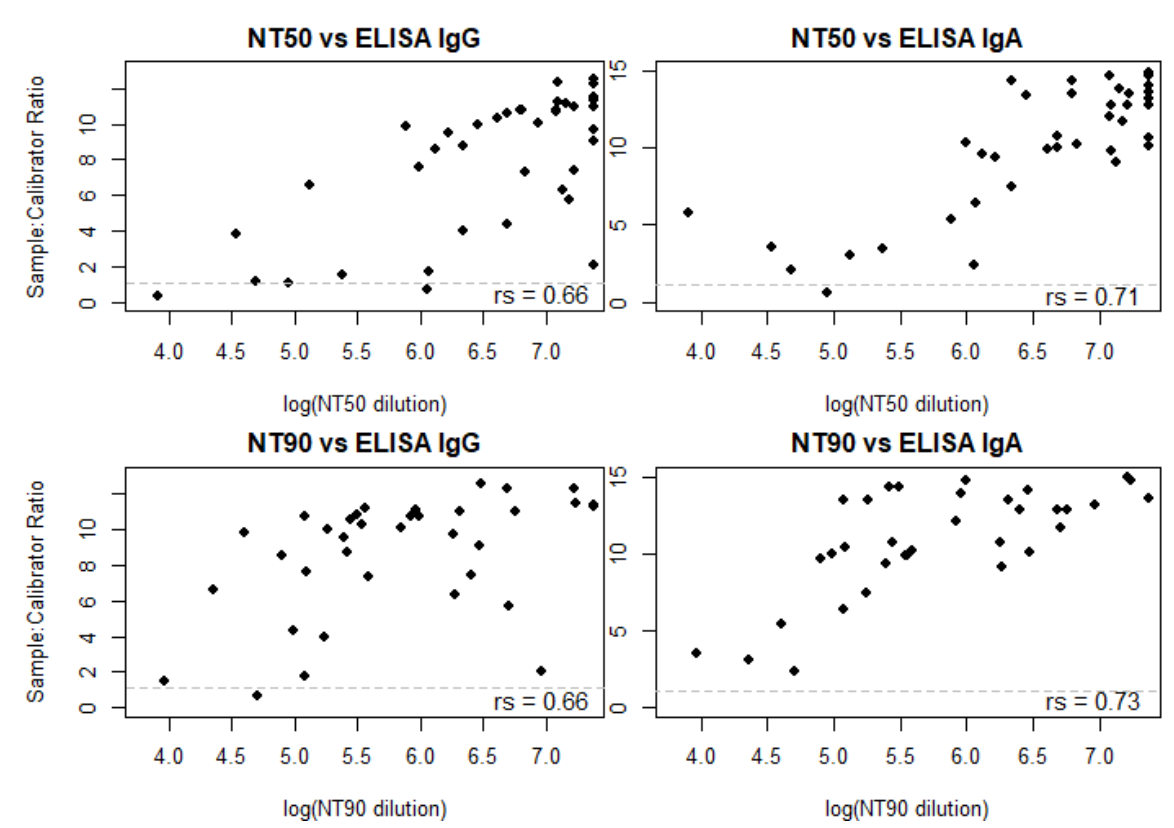

Fig 5: Correlations between the NT50/NT90 and Euroimmun IgG/ IgA ELISA ratios, as calculated by the nonparametric Spearman correlation test ( $r s)$. Seropositivity cut-off levels are indicated by the dashed grey lines.

\section{Discussion}

While a plethora of commercial serological tests became available months after the discovery of SARS-CoV-2, researchers have already experienced problems in terms of sensitivity and specificity with many early market commercial tests ${ }^{9}$. Problems may arise because tests are mainly evaluated on sera from severe COVID-19 patients, who are suggested to develop a much higher immune response than mild or asymptomatic cases ${ }^{25}$. Here, we convincingly show that neutralizing and binding IgG antibody levels are indeed significantly higher for severe than mild/asymptomatic cases in the early convalescent phase ( $<6$ weeks) (Fig 1). Furthermore, given that antibody levels directed to other human coronaviruses are known to decrease rapidly after infection (usually after $0.5-1$ year) ${ }^{26,27}$ and seroreversions (antibody positive to negative) are already noted for asymptomatic SARS-CoV- 2 infections ${ }^{28}$, we expect that antibody levels of the majority of mild/asymptomatic cases might drop below the cut-off value of many diagnostic tests within months to a year after infection. While we highlight that seroreversion does not necessarily mean that recovered people will become susceptible for COVID-19 months after the infection (immunity also depends on the T-cell mediated immune responses that might last much longer $)^{29}$, it is clear that this issue will complicate the epidemiological assessment and should be taken into account by mathematical models that aim to understand/predict the transmission dynamics in the population ${ }^{3,14}$. This issue also raise questions related to vaccine development. Indeed, if humoral immunity would already decrease rapidly after natural infection, concerns exist that vaccines may not be able to trigger a sufficiently high and long-lasting protective antibody-mediated immune response ${ }^{30}$. 
medRxiv preprint doi: https://doi.org/10.1101/2020.07.25.20161943; this version posted July 27,2020 . The copyright holder for this preprint (which was not certified by peer review) is the author/funder, who has granted medRxiv a license to display the preprint in perpetuity. It is made available under a CC-BY 4.0 International license .

$16 / 07 / 2020$

The ROC analyses showed that NP, RBD and S1S2 antigens together can be used to develop a highly specific (99\%) and sensitive (96\%) Luminex SARS-CoV-2 antibody detection assay. Although these antigens performed well in singleplex (table 1), a combination of the three antigens clearly increased the assay's prediction performance in comparison to the best performing singleplex ( $R B D, \triangle A \cup C=0.022$ ). The increase in specificity is explained by the multiplexing of three antigens in relation to the random forest algorithm. For example, a few aspecific bindings were noted in the negative control samples (4x NP and 1x RBD, S1 and S2) (Fig 2). While these samples would clearly be categorized as positives in a singleplex, they were actually categorized as negative by the random forest as the aspecific bindings did not happen in the same sample. This aspect makes a multiplex assay appealing for serosurveillance in sub-Saharan Africa, where malaria is notoriously known to cause false positive results in serological assays ${ }^{31}$. Interestingly, while RBD clearly outperformed the other antigens in a singleplex for classification (Table 2), antibody levels to NP were only slightly lower for severe than mild cases (Fig 1). This could be relevant in the light of a weaker immune response in mild/asymptomatic cases, suggesting that NP antibody levels might be easier to pick-up during serosurveillance studies (higher sensitivity) ${ }^{21}$, especially when overall antibody titers would decrease over time ${ }^{27}$. Consequently, a combination of NP with RBD/S1S2 is also put forward in two independent Luminex bead-based assays that were recently published ${ }^{12,13}$.

Because VNTs are labour-intensive, require biosafety level-3 (BSL-3) conditions and specific training skills, simple serological tests that could predict individual levels of protectingimmunity are highly needed to assess the effect of vaccine campaigns ${ }^{19}$. For this reason, we correlated neutralizing titers (NT50 and NT90) to antibody levels obtained by our Luminex assay and a commercial ELISA. We found moderate-to-weak correlations to NP ( $\mathrm{rS}_{\mathrm{NT5O}} \mathrm{NP}=0.43$; $\mathrm{rS}_{\mathrm{NT9O}} \mathrm{NP}=0.41$ ), probably because antibody levels already reached the maximum $\triangle \mathrm{MFI}$ at low NT50 and NT90. The highest correlations were observed to the S1-antigen ( $\mathrm{rS}_{\mathrm{NT50} \_\mathrm{IgG}: \mathrm{S1}}=0.66$; $r_{\text {NT90_lgG:S1 }}=0.68$ ). Given that $S 1$ is also the antigen target of the Euroimmun ELISA and our Luminex assay correlated strongly with the IgG ELISA in singleplex, it is no surprise that the IgG ELISA ratios correlate similarly with the neutralizing titers. While the inclusion of $\mathrm{S} 1$ to the Luminex bead set does not significantly improve the prediction performance of the test (Table 2), it can be included to better predict levels of neutralizing antibodies (this will only slightly increase the price per sample). Interestingly, the highest correlations were observed with the IgA ELISA ( $r S_{N T 50 \_I g A: S 1}=0.71 ; r_{N T 90}$ IgA:S1 $=0.73$ ), indicating that IgA might be a better predictor of neutralizing antibody levels than IgG during the early convalescent phase ( $<6$ weeks).

In conclusion, we have developed a highly sensitive and specific serological assay for the detection of SARS-CoV- 2 IgG antibodies using a robust and high-throughput technology. Our assay can predict neutralizing antibody levels in the early convalescent phase relatively accurately. We also found that neutralizing titers and binding IgG antibodies differ significantly between severe and mild/asymptomatic COVID-19 cases, indicating that serological tests are 
medRxiv preprint doi: https://doi.org/10.1101/2020.07.25.20161943; this version posted July 27, 2020. The copyright holder for this preprint (which was not certified by peer review) is the author/funder, who has granted medRxiv a license to display the preprint in perpetuity.

It is made available under a CC-BY 4.0 International license .

$16 / 07 / 2020$

best evaluated on serum panels that include mild and asymptomatic cases before use in largescale serosurveillance settings.

\section{Ethics statement}

Approval to sample from COVID-19 cases was obtained from the Ethical committee of the University of Ghent (BC-07587), local committees of each participating hospital and all participants provided consent to participate. The use of prepandemic leftover samples was approved by ITM's internal review board. We declare that the planning conduct and reporting of the study was in line with the Declaration of Helsinki, as revised in 2013.

\section{Funding}

The work was funded by a European \& Developing Countries Clinical Trials Partnership (EDCTP) project (Africover: RIA2020EF-3031), the Research Foundation Flanders (FWO) (G0G4229N and G054820N) and intramural funds from the Institute of Tropical Medicine Antwerp. Joachim Mariën is a member of the Outbreak Research Team which is funded by the Department of Economy, Science and Innovation of the Flemish government in Belgium (EE145 4150).

\section{Acknowledgements:}

We thank Laure Mortgat, Elza Duysburgh, Natalie Fischer, Isabelle Thomas, Cyril Barbezange, Veronik Hutse for the organization of the Health Care Worker seroprevalence study (Sciensano/ITM, NCT04373889).

\section{Author contributions}

Conceived the study: JMa, MAW and KA. Wrote the paper: JMa. Performed the lab experiments: JMa, JMi, LH, KK, and NF. Performed the statistical analyses: JMa. Supervised data collection and laboratory work: ID, HJ, MvE and KA. All authors read and approved the final manuscript.

\section{$\underline{\text { References }}$}

1. Johns Hopkins University. COVID-19 Dashboard by the Center for Systems Science and Engineering (CSSE). https://coronavirus.jhu.edu/map.html (2020). doi:10.1136/bmj.2.5361.864

2. Centers for disease control and prevention. Commercial Laboratory Seroprevalence Survey Data. https://www.cdc.gov/coronavirus/2019-ncov/cases-up https://www.cdc.gov/coronavirus/2019-ncov/cases-up (2020). Available at: https://www.cdc.gov/coronavirus/2019-ncov/cases-updates/commercial-labsurveys.html.

3. Borremans, B. et al. Quantifying antibody kinetics and RNA shedding during earlyphase SARS-CoV-2 infection. medRxiv 10.1101/2020.05.15.20103275 (2020). doi:10.1101/2020.05.15.20103275 
medRxiv preprint doi: https://doi.org/10.1101/2020.07.25.20161943; this version posted July 27, 2020. The copyright holder for this preprint (which was not certified by peer review) is the author/funder, who has granted medRxiv a license to display the preprint in perpetuity. It is made available under a CC-BY 4.0 International license .

$16 / 07 / 2020$

4. Corman, V. M. et al. Detection of 2019 novel coronavirus (2019-nCoV) by real-time RTPCR. Euro Surveill. 25, 1-8 (2020).

5. Hu, Z. et al. Clinical characteristics of 24 asymptomatic infections with COVID-19 screened among close contacts in Nanjing, China. Sci. China Life Sci. 63, 706-711 (2020).

6. Zhang, W. et al. Molecular and serological investigation of 2019-nCoV infected patients: implication of multiple shedding routes. Emerg. Microbes Infect. 9, 386-389 (2020).

7. Lassaunière, R. et al. Evaluation of nine commercial SARS-CoV-2 immunoassays. medRxiv 1-15 (2020).

8. Okba, N. M. A. et al. SARS-CoV-2 specific antibody responses in COVID-19 patients. medRxiv (2020). doi:10.1101/2020.03.18.20038059

9. Krammer, F. \& Simon, V. Serology assays to manage COVID-19. Science 1227, 1-5 (2020).

10. Xun, J. et al. Neutralizing antibody responses to SARS-CoV-2 in a COVID-19 recovered 2 patient cohort and their implications. The lancet (preprint) (2020).

11. Amanat, F. et al. A serological assay to detect SARS-CoV-2 seroconversion in humans. Nat. Med. (2020). doi:10.1101/2020.03.17.20037713

12. Dobaño, C. et al. Highly sensitive and specific multiplex antibody assays to quantify immunoglobulins $M, A$ and $G$ against SARS-CoV-2 antigens. bioRxiv (2020). doi:10.1101/2020.06.11.147363

13. Ayouba, A. et al. Multiplex detection and dynamics of IgG antibodies to SARS-CoV2 and the highly pathogenic human Coronaviruses SARS-CoV and MERS-CoV. J. Clin. Virol. 104521 (2020). doi:10.1016/j.jcv.2020.104521

14. Rosado, J., Cockram, C., Merkling, S. H., Demeret, C. \& Meola, A. Serological signatures of SARS-CoV-2 infection : Implications for antibody-based diagnostics. medRxiv 1-30 (2020).

15. Kerkhof, K. et al. Implementation and application of a multiplex assay to detect malaria-specific antibodies: a promising tool for assessing malaria transmission in Southeast Asian pre-elimination areas. Malar. J. 14, 1-14 (2015).

16. Taskin Tok, T., Tatar, G. \& Tugba, T. T. Structures and Functions of Coronavirus Proteins: Molecular Modeling of Viral Nucleoprotein-International Journal of Virology \& Infectious Diseases International Journal of Virology \& Infectious Diseases. Int. J. Virol. Infect. Dis. 2, 1-7 (2017).

17. Wang, C. et al. A human monoclonal antibody blocking SARS-CoV-2 infection. Nat. Commun. 11, 1-6 (2020).

18. Walls, A. C. et al. Structure, Function, and Antigenicity of the SARS-CoV-2 Spike Glycoprotein. Cell 181, 281-292.e6 (2020).

19. Premkumar, L. et al. The receptor binding domain of the viral spike protein is an immunodominant and highly specific target of antibodies in SARS-CoV-2 patients. Sci. Immunol. 5, 1-9 (2020).

20. Padron-Regalado, E. Vaccines for SARS-CoV-2: Lessons from Other Coronavirus Strains. Infect. Dis. Ther. 9, 255-274 (2020).

21. Burbelo, P. D. et al. Detection of Nucleocapsid Antibody to SARS-CoV-2 is More Sensitive than Antibody to Spike Protein in COVID-19 Patients. arXiv 53, 1689-1699 (2015).

22. Reed, L. \& Muench H., A. A simple method of estimating fifty per cent endpoints. Am J 
medRxiv preprint doi: https://doi.org/10.1101/2020.07.25.20161943; this version posted July 27, 2020. The copyright holder for this preprint (which was not certified by peer review) is the author/funder, who has granted medRxiv a license to display the preprint in perpetuity. It is made available under a CC-BY 4.0 International license .

$16 / 07 / 2020$

Hyg 27, 493-497 (1938).

23. Ambrosino, E. et al. A multiplex assay for the simultaneous detection of antibodies against 15 Plasmodium falciparum and Anopheles gambiae saliva antigens. Malar. J. 9, 1-12 (2010).

24. Breiman, L. \& Cutler, A. Package 'randomForest'. Cran Repos. (2018). doi:10.1023/A

25. Zhang, Z. et al. Early viral clearance and antibody kinetics of COVID-19 among asymptomatic carriers. medRxiv (2020).

26. Edridge, A. W. D. et al. Human coronavirus reinfection dynamics: lessons for SARSCoV-2. Medrxiv 1-10 (2020). doi:10.1101/2020.05.11.20086439

27. Edridge, A. W. D. et al. Coronavirus protective immunity is short-lasting. medRxiv 2020.05.11.20086439 (2020). doi:10.1101/2020.05.11.20086439

28. Long, Q. X. et al. Clinical and immunological assessment of asymptomatic SARS-CoV-2 infections. Nat. Med. (2020). doi:10.1038/s41591-020-0965-6

29. Gutierrez, L., Beckford, J. \& Alachkar, H. Deciphering the TCR Repertoire to Solve the COVID-19 Mystery. Trends Pharmacol. Sci. 1-13 (2020). doi:10.1016/j.tips.2020.06.001

30. Callaway, E. Coronavirus vaccines: five key questions as trials begin. Nature $\mathbf{5 7 9}, 481$ (2020).

31. Esbroeck, M., Meersman, K., Michiels, J., Ariën, K. \& Bossche, D. Van den. Specificity of Zika virus ELISA: interference with malaria. Euro Surveill. 29, 252-262 (2016). 